\title{
INFORMÁCIÓKÖZLÉS DIAGRAMOK HASZNÁLATÁVAL
}

\author{
Hampel György
}

\begin{abstract}
Absztrakt: A tudásalapú és információval átszőtt társadalomban a hatékony adat- és információátadás nélkülözhetetlen a mindennapi boldoguláshoz. Az adatnak és információnak, amelyet a hétköznapi életben többnyire egymás szinonimájának tekintünk, többféle meghatározása létezik. Amennyiben különbséget teszünk a két fogalom között, mondhatjuk, hogy az információ több mint adat. Az információt valamilyen módon továbbítani kell a befogadó (személy) felé és számos megjelenési módja létezik (szöveg, kép, hang stb.). A kognitív pszichológia az embert lényegében információfeldolgozó „egység”-nek tekinti. A közölni kívánt információt úgy kell továbbítani, hogy a befogadó fél azt gyorsan megértse. A diagramok hatékony eszközei lehetnek az információ közlésének, amennyiben helyesen alkalmazzuk azokat. Diagrammal ábrázolható trend, összefüggés, kivétel stb. Jelen publikáció néhány ismertebb diagramtípussal foglalkozik, azok fő jellemzőivel, a hozzájuk kapcsolódó ajánlásokkal és a készítésük során előforduló gyakori hibákkal.
\end{abstract}

\begin{abstract}
In a knowledge-based and information-rich society, the effective transfer of data and information is essential to get on every day. Data and information - which are mostly used as synonyms to each other - have several definitions. If we distinguish between the two concepts, we can say that information is more than data. The information has to be transmitted in some way to the recipient (person), and it has several appearances (text, image, sound, etc.). According to cognitive psychology, humans are information-processing "units". The information has to be communicated in such a way that it is quickly understood by the receiving party. If applied correctly, charts can be an effective way to transmit information, and they can represent trends, correlation exception, etc. This publication deals with some of the well-known types of charts, their main features, recommendations, and common errors that occur during their creation.
\end{abstract}

Kulcsszavak: adat és információ, információfeldolgozás, grafikus ábrázolás, diagram

Keywords: data and information, information processing, graphical representation, charts

\section{Az emberi információfeldolgozás kognitív modellje}

A tudásalapú társadalomban az információ ugyanúgy erőforrásnak tekintendő, mint az ún. hagyományos (természeti, pénzügyi, emberi) erőforrások. Szervezetek nem lehetnek sikeresek olyan (számítógép által is támogatott) rendszer nélkül, amely nem járul hozzá az adatok, majd az azokból képzett információk gyüjtéséhez, tárolásához, feldolgozásához és visszakereséséhez, megjelenítéséhez.

Az adatnak és információnak számos definíciója létezik, amelyek egy része a két fogalmat gyakorlatilag egymás szinonimájának tekinti (objektív információértelmezés), míg más meghatározások igyekeznek a két fogalmat - különböző szempontok alapján - egymástól elhatárolni; csak egy példa: Az adat egy elem (objektum) egy meghatározott tulajdonságának (jellemzőjének, attribútumának) értéke, állapota, rögzített jellemzője, amelyet megfigyeléssel, méréssel állapíthatunk meg (Juhász, 2011). Az információ olyan tájékoztatás, közlés, adat, ismeret, hír, amely a címzett által értelmezhető és célja a bizonytalanság csökkentése (HampelHeves, 2019). A gyakorlatban a két fogalom elkülönítése nem egyértelmü; ennek oka, hogy függ az adott helyzettől és a befogadó fél háttértudásától is (KacsuknéKiss, 2009). Jelen cikkben nem teszünk különbséget a két fogalom között, azonosnak tekintjük azokat. 
Az információ közlés (kommunikáció) során adható át (1. ábra): A kommunikációt a felek (többnyire) információközlés céljából indítják el. A közlendö információt a továbbításhoz kódolni kell, át kell alakítani a közlésre alkalmas adatformára annak érdekében, hogy továbbítható legyen az igénybe vett átviteli csatornán. A kódolt információ (hír, közlemény) a csatornán keresztül továbbítódik és eközben számos zajforrásból származó zavaró hatás miatt torzulhat. A torzított hír eljut a címzetthez, aki/ami azt értelmezi (Bodnár-Magyary, 2005)

\section{1. ábra: A kommunikáció modellje}

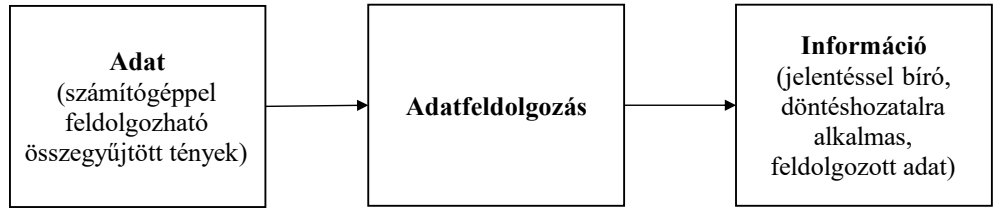

Forrás: Bodnár-Magyary (2005) alapján saját szerkesztés.

A kognitív pszichológia az egyént lényegében információfeldolgozó „egységnek” tekinti, ahhoz hasonlóan, mint mikor egy számítógép egy adatból/információból valamilyen algoritmus, program (gondolkodási folyamat) végrehajtása révén elóállítja az outputot. A számítástechnika fejlődése az 1950-es és 1960-as években jelentős hatással volt a pszichológia tudományának alakulására azzal, hogy a számítástechnika egyfajta analógiát, metaforát kínált a pszichológusok számára, amelyet össze tudtak hasonlítani az emberi elme müködésével (AtkinsonShiffrin, 1968). Az 1970-es, 1980-as években domináns „memória modell” egy háromkomponensủ információfeldolgozó rendszer, amelyet egy tipikus számítógéparchitektúra inspirált. Eszerint létezik:

- Szenzoros emlékezet: érzékszervhez kötődő memória, amellyel az inger megszünése után is meg tudjuk tartani az érzékelt információt egy nagyon rövid ideig (néhány száz milliszekundumig). Számítástechnikában ez az input eszközöknek (például billentyüzet, hangfelismerő rendszer stb.) felel meg.

- Rövid távú memória, munkamemória: Néhány másodpertől néhány percig tárol információt, de nem (csak) passzívan, hanem aktívan alakítja azt (feldolgozza, átalakítja). Tárolókapacitása meglehetősen korlátozott, kutatók szerint $5 \pm 2$ információnál többet nem képes egyidőben tárolni. A számítógép processzorának (CPU) vagy közvetlen hozzáférésü memóriájának (RAM) felel meg.

- Hosszú távú memória: Az információk hosszú távú tárolására szolgál, a szakemberek szerint az előző kettő memóriával ellentétben nincs kapacitáskorlátja. Ez a fajta memória analóg a számítógép háttértárával, például egy merevlemezzel, vagy szilárdtest meghajtóval (némi különbséggel: a számítógép háttértárának van kapacitáskorlátja, viszont a bekerült információ nem módosul - ellentétben az emberi hosszú távú memóriával). 
Wickins és munkatársai (2013) modellje szerint az információfeldolgozási folyamat lépések sorozata, folyamatos visszacsatolással (lásd: 2. ábra):

- Érzékszervi (szenzoros) feldolgozás és tárolás: Információk, események az érzékszerveinken keresztül jutnak az emberi agyba és mind meghatározzák az információ minőségét. Minden érzékszervnek van saját rövid távú memóriája (néhány másodperc).

- Észlelés: A környezetből érkező nyers adat észlelése. Jellemzője, hogy automatikus és gyors, kevés figyelmet követel, befolyással van rá mind a szenzoros input, mind a hosszú távú memória.

- Felfogás, megismerés (gondolkodás): Ez a folyamat rendszerint időigényesebb és több mentális erőfeszítést igényel, mint az előző lépések, mivel az agynak különbözö tevékenységeket kell végeznie a rövid távú memóriát is igénybe véve (gyakorlás, érvelés stb.).

- Memória: Az információ először a könnyen megzavarható munkamemóriában tárolódik, majd kellő számú ismétlés, gyakorlás stb. után a hosszú távú memóriába kerül.

- Válasz kiválasztása és végrehajtása: Egy érzékszervvel felfogott és gondolkodási folyamattal megértett szituáció gyakran valamilyen reakciót vált ki. Ezt követi a reakció végrehajtása, amely például a test mozgatásához szükséges izom-koordinációt igényli a kívánt cél elérése érdekében.

- Visszacsatolás: A végrehajtott cselekvéseket az ember érzékeli, erről az információáramlás folyamatos, ez biztosítja, hogy a cél elérése sikeres legyen.

- Figyelem: Számos mentális folyamat nem automatikus, itt van jelentősége a figyelemnek, ami biztosítja (kiválasztja), hogy mely folyamatok részesüljenek a korlátozottan rendelkezésre álló erőforrásokból. Amennyiben túl sok feladatot kell egyszerre végrehajtani, a következmény a figyelem megosztása, amelynek eredménye, hogy egyes feladatok hátrányba kerülnek.

\section{2. ábra: Az emberi információfeldolgozás modellje}

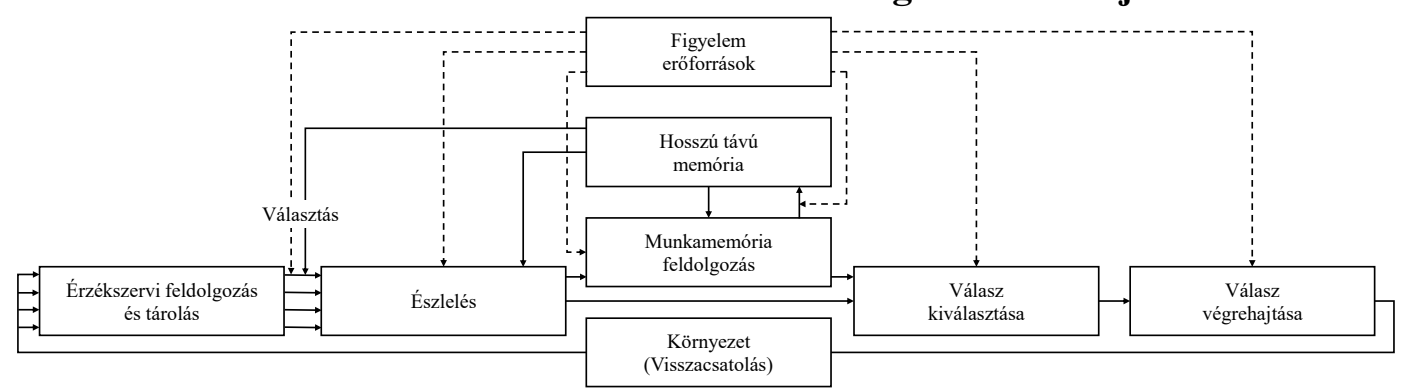

Forrás Wickens et al. (2013) alapján saját szerkesztés.

A közölt információ számos formátumban jelenhet meg (Juhász, 2011). Lehet:

- hangalapú (élőszó, hangfelvétel),

- szövegformátumú (írott, nyomtatott, digitalizált), 
- strukturált szám-, vagy kódhalmaz (írott, nyomtatott digitalizált),

- képi (álló vagy mozgó, kézzel rajzolt, nyomtatott, digitalizált).

A hangalapú és a szövegformátumú közlés lehet akár igen terjedelmes és minden részletre kiterjedő - csak legyen, aki végighallgatja, vagy elolvassa és megérti.

A strukturált szám- vagy kódhalmaz lehet egy lista (felsorolás) vagy táblázat, amely az alapadatokon kívül számos statisztikai jellegü és adattömörítésre alkalmas adatot (leíró és következtetési statisztikát) tartalmazhat.

Szokás mondani: egy kép többet mond ezer szónál. Egy állókép is alkalmas nagy mennyiségü információ tárolására és közlésére, ráadásul sokkal gyorsabban felfogható, megérthető mint a hangalapú, vagy szövegformátumú közlés. Képi információközlés lehet például egy folyamatot leíró ábra, vagy számokat, statisztikákat ábrázoló diagram.

\section{Diagramok használata az információ közlésére}

A diagram az információ szimbolikus ábrázolása vizualizációs technológiák alkalmazásával. Használata végig kísérte az emberiség történetét (...már az ősember is a barlangrajzaival...), de igazi jelentősége a felvilágosodás korával jött el (Eddy, 2020).

Az információ ábrázolására ma már számos diagramtípus áll rendelkezésre, amelyek más-más módon kínálnak betekintést adatokba, illetve teszik lehetővé, hogy az adatok közötti összefüggéseket meglássuk. Az ábrázoláshoz tudnunk kell, hogy mi a szándékunk, mi az az információ, amit közölni szeretnék, mi az a történet, amit el kívánunk mesélni (például trendeket, összefüggéseket, vagy kivételeket szeretnénk láttatni, lásd: 3. ábra).

\section{3. ábra: Az információközlés célja}

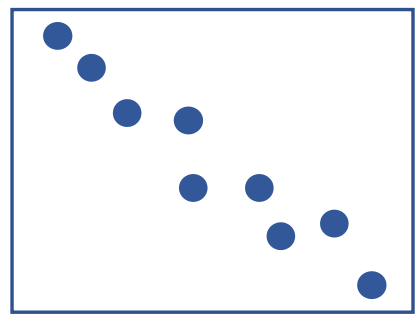

Trend

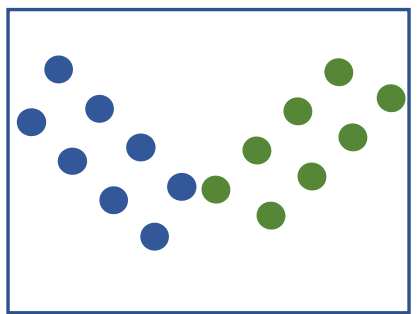

Összefüggés

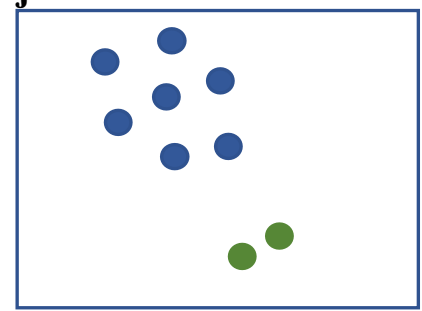

Kivétel

Forrás: HubSpot (2014) alapján saját szerkesztés.

Kvantitatív - azaz megszámolható vagy mérhető, számértékkel kifejezhető adatokat tudunk ábrázolni. A kvalitatív (minőségi) adatokat az ábrázoláshoz kvantitatív adatokká kell alakítani. A kvantitatív adat lehet:

- diszkrét: számadat véges számú lehetséges értékekkel (dolgozók száma egy adott munkahelyen),

- folytonos: egy tartományon belül tetszőleges számértéket vehet fel (éves búzatermés),

- kategorikus: csoportokba sorolható, rendezhető (eladott terméktípusok). 
Az adatok közötti kapcsolatok figyelembevételével általában a következő feladatok valamelyike végezhetö el: (lásd: 4. ábra)

- összehasonlítás: különböző csoportokba tartozó számadatok egyszerü összevetése (weboldalak látogatóinak száma),

- idősor vizsgálata: adott időszak alatt az adatok alakulása, változása (havi termékeladások),

- összefüggés vizsgálata: két vagy több változó (adatsor) értékei hogyan hatnak egymásra (végzettség és jövedelem kapcsolata),

- rangsorolás: két vagy több érték hogyan viszonyul egymáshoz (búzatermés az elmúlt tíz évben a legnagyobbtól a legkisebbig),

- eltérés vizsgálata: milyen az adatok közötti viszony, egy adat mennyire tér el a középértéktöl (külföldi turisták száma Magyarországon a 2020-as világjárvány idején egy átlagos évhez képest),

- eloszlás vizsgálata: adatok eloszlása, általában egy központi érték, középérték körül (munkavállalók jövedelmének eloszlása),

- rész és egész viszonya: az adatok egy részhalmazának viszonya egy nagyobb (teljes) halmazhoz (egy adott terméket vásárlók aránya).

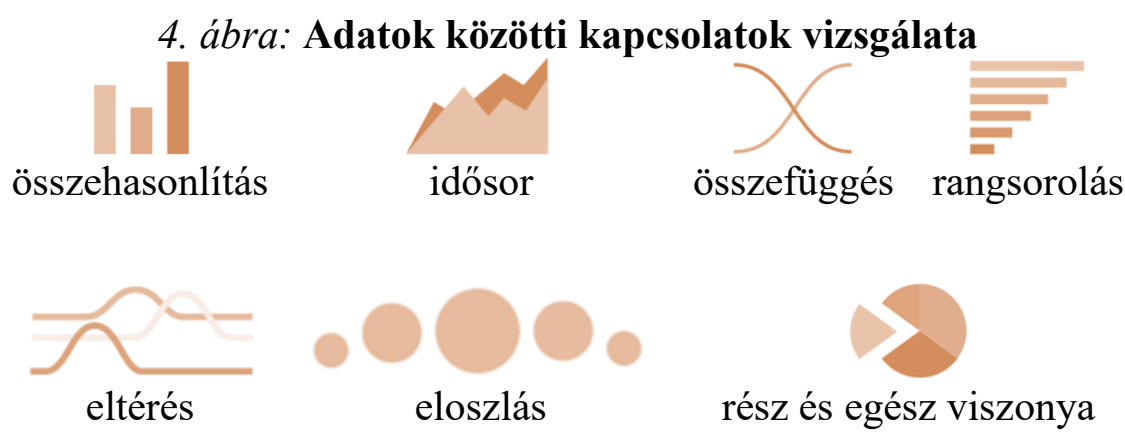

Forrás: HubSpot (2014) alapján saját szerkesztés.

Amennyiben tisztában vagyunk azzal, hogy a fenti lehetőségek közül mi az, amit információként közölni szeretnénk, következhet a megfelelö diagramtípus kiválasztása.

A jól megválasztott ábrázolási mód segítheti az elemzést, az összefüggések feltárását; Fabulya (2017) egy lehetséges alkalmazást mutat be a hőkezelési folyamatok összehangolására, melyet diagramok is jól szemléltetnek. Az ábrázolásra számos szoftver áll rendelkezésre, amelyek igen sokféle ábrázolási lehetőséget kínálnak a felhasználónak. Előfordul, hogy a programokban felkínált számos lehetőség a felhasználót zavarba ejti és olyan „mestermüvekre” inspirálja, amelyek

- a mondanivaló szempontjából nem megfelelő formátumúak, vagy

- az adott szakterületen szokatlanok,

- (információ)hiányosak,

- felesleges, redundáns adatokat tartalmaznak.

A megfelelő ábrázolási mód kiválasztása majd annak helyes használata (például feliratozása) alapvető fontosságú, mert a helytelen használat nehezen 
értelmezhetővé, vagy akár teljesen értelmezhetetlenné teheti a közölni kívánt információt.

A grafikus ábrázolással szembeni elvárások, alapelvek a következők (Domán et al., 2007): Az ábra legyen

- áttekinthető, azt mutassa, amire szolgál. A számítógépes programok sok olyan megoldást biztosítanak, amelyek arra csábítanak, hogy olyan helyzetben is használjuk azokat, amikor egyébként teljesen feleslegesek, csak arra jók, hogy elvonják a lényegröl a figyelmet. Ebbe beleértendő a színek, alakzatok vagy egyéb formai megoldások alkalmazása. A színek, illetve színárnyalatok kiválasztásánál ügyelni kell arra, hogy egyes színekkel ki tudunk emelni (vagy éppen ellenkezőleg), gondolni kell arra, hogy a színtévesztők másként látják a színeket, valamint nem mindegy az sem, hogy a képernyőn esetleg színes ábra hogyan fog szürke színárnyalatú vagy feketefehér nyomtatásban a papíron megjelenni.

- célorientált, homogén, egyszerre csak egy jelenséget ábrázoljon. A két eltérö tengelyfeliratozással, vagy skálázással rendelkező, vagy egyszerre többféle diagramtípust tartalmazó ábrák zavarhatják a megértést még akkor is, ha egyébként összetartozó jelenséget próbálnak meg ábrázolni.

- egyszerü, azaz nem szükséges - ugyan látványos, de - a megértést csak nehezítő, felesleges megoldásokat alkalmazni, amelyekre a mai számítógépes programok úgyszintén csábítanak. A háromdimenziós ábrák (például egy marketing kiadványban) első ránézésre kétségkívül szebb látványt nyújtanak mint a kétdimenziós változatuk, de ha a harmadik dimenziónak semmilyen információtartalma nincs, akkor nem csak felesleges, hanem a gyors áttekintés és megértés szempontjából káros is az alkalmazásuk.

- rekonstruálható, ami azt jelenti, hogy az adatok forrását és az alkalmazott módszertani elemeket is fel kell tüntetni (akár az ábrán, akár az ábrához tartozó leírásban). Ezen kívül az ábrát el kell látni feliratozással, amelyből kiderül, hogy mit ábrázol, hol, mikor, milyen mértékegységben, továbbá az ábra típusától függően a tengelyeket is feliratozni kell, és jelmagyarázatra is szükség lehet.

- optikailag semleges, azaz grafikai trükkökkel nem szabad befolyásolni a közölni kívánt információt. Ha az ábra koordinátarendszert tartalmaz, a tengelyek skálabeosztásának - akár szándékosan, akár szándékolatlanul nem megfelelö megválasztása alkalmas lehet a manipulációra. Ugyanitt lehet megemlíteni a színek, színárnyalatok fontosságát is, hiszen a megfelelő színnel ki tudunk emelni valamilyen adatot, jobban rá tudjuk irányítani a figyelmet, de ez is alkalmas lehet a manipulálásra.

\section{Gyakori diagramtípusok}

A következőkben bemutatom a leggyakrabban használt diagramtípusokat és hozzájuk kapcsolódóan olyan ajánlásokat (best practices), amelyek - alkalmazásuk esetén - sikeresebbé tehetik a diagram megértését, azaz hatékonyabbá tehetik az 
információátadást. A diagramok a Microsoft 365 irodai programcsomag Excel táblázatkezelőjével készültek, a felhasznált adatok a KSH tájékoztatási adatbázisából származnak.

\subsection{Oszlop- és sávdiagram}

Széleskörüen használható és szinte minden diszkrét és folytonos adat szemléltethető a segítségével; elsősorban csoportosítás, vagy összehasonlítás céljára szolgál. Amennyiben idősort ábrázol, az balról jobbra kell haladjon. A negatív értékek a vízszintes tengely alatt jelennek meg. A sávdiagram egy 90 fokban elforgatott oszlopdiagramnak felel meg. Az egyik tengelyén a kategóriák (feliratok), a másik tengelyén valamilyen skálán skálabeosztás található. Csoportosított elrendezésnél az adatokat tartalmazó oszlopok egymás mellé kerülnek, halmozott oszlop esetén pedig egymásra. Néhány példa látható az 5. ábrán.

\section{5. ábra: Oszlopdiagram}

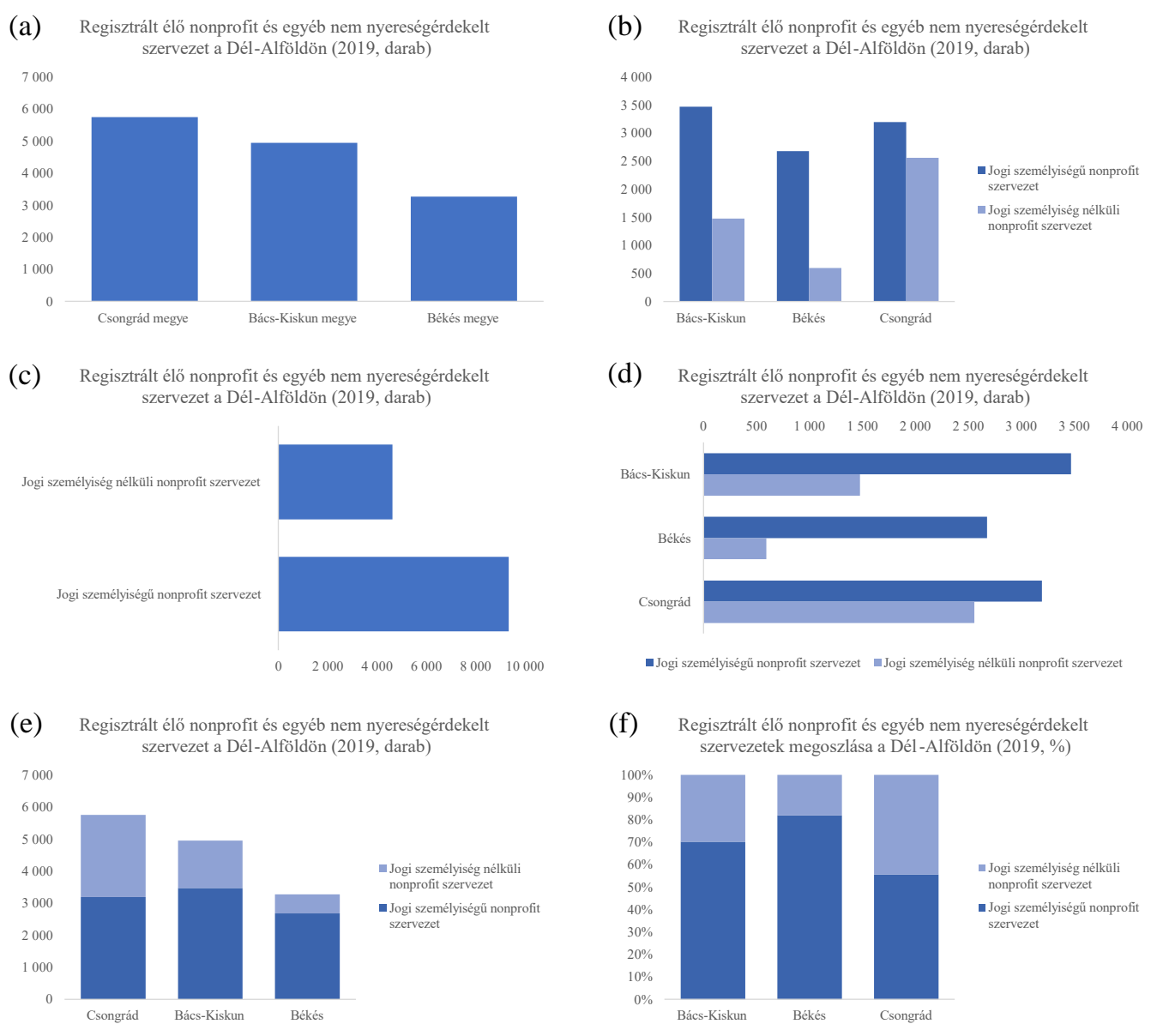

a) oszlopdiagram, b) csoportosított oszlopdiagram, c) sávdiagram $\left(90^{\circ}\right.$-kal elforgatott oszlop), d) csoportosított sávdiagram, e) halmozott oszlopdiagram, f) 100\%-ig halmozott oszlopdiagram

Forrás: KSH adatok alapján saját szerkesztés. 
Ajánlások:

- Ha az oszlophoz tartozó felirat vízszintesen kiírva nem fér ki, forgassuk el az oszlopdiagramot $90^{\circ}$-kal! Ezzel sávdiagram lesz belőle.

- A két tengely az $\mathrm{y}=0$ pontban metssze egymást!

- Az oszlopok közötti térköz szélessége az oszlopok szélességének fele legyen!

- Az oszlopok színezésére használjuk ugyanannak a színnek a különböző árnyalatait. Ha valamelyik oszlopot ki akarjuk emelni, akkor arra használjunk eltérő színezést, vagy keretezzük be a kiemelni kívánt oszlopot!

- Az oszlopokat rendezzük logikai sorrendbe (érték, ábécé vagy időrend szerint)!

A 6. ábra az oszlopdiagramok készítése során gyakran elkövetett hibákat mutatja.

\section{6. ábra: Oszlopdiagramok készítése során elkövetett hibák}

(a)

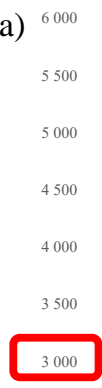

(c)
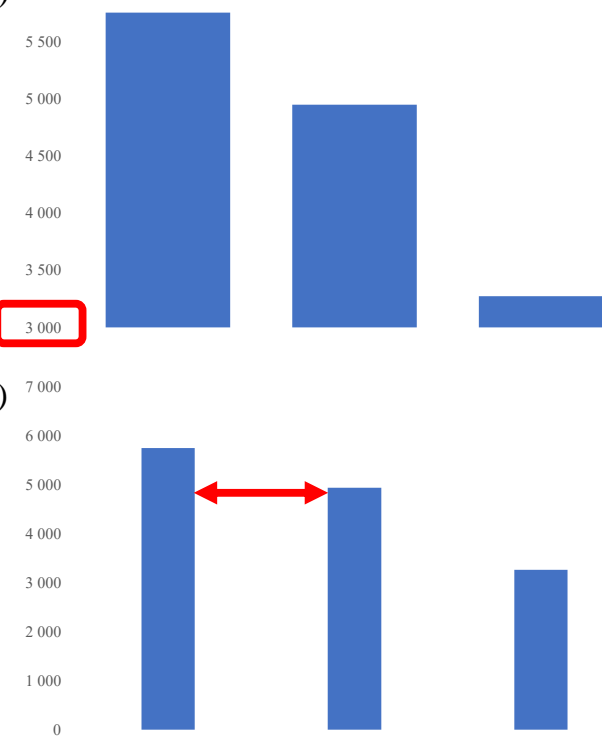

(e)

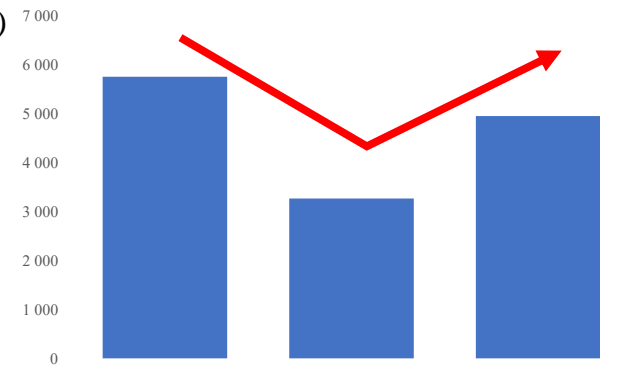

(b)
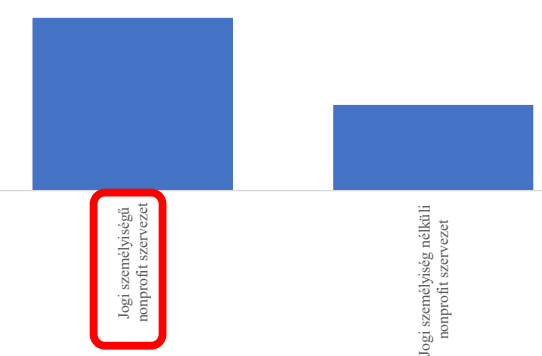

(d) 7000
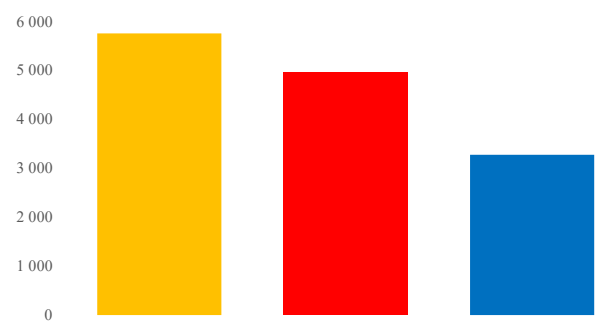

(f)

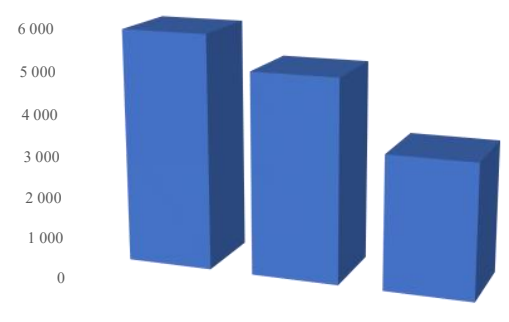

a) nem 0 kezdőpont, b) elforgatott és ezért nehezen olvasható szöveg, c) túl nagy térköz az oszlopok között, d) különböző színű oszlopok, e) oszlopok nem logikai (pl. csökkenő) sorrendben

f) harmadik, információtartalom nélküli dimenzió Forrás: saját szerkesztés. 


\subsection{Kördiagram}

A kördiagram részek egymáshoz való viszonyának szemléltetésére használható abban az esetben, ha a szemléltetni kívánt diszkrét vagy folytonos adatsor nem túl nagy (lásd: 7. ábra). Bár egy gyakran használt diagramtípusról van szó, ez az ábrázolási forma csak akkor hatékony, ha a körcikkek mérete kellöképpen különbözik egymástól (aligha vagyunk képesek például egy $20^{\circ}$-os és egy $23^{\circ}$-os körcikk között különbséget tenni), illetve, ha 25\%, 50\%, 75\%, 100\%-os (vagy azokhoz közeli) arányokat kell szemléltetni. Ettől eltérő arányokat nem egyformán értékelünk, így az összehasonlítás is nehézkes.

\section{7. ábra: Kördiagram}

(a) Regisztrált gazdasági szervezetek gazdálkodási formák szerint a Dél-Alföldön (2019. december, N=260 423, \%)
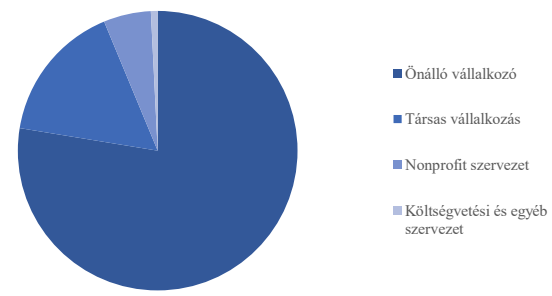

(c) Regisztrált gazdasági szervezetek gazdálkodási formák szerint a Dél-Alföldön (2019. december, N=260 423, \%)

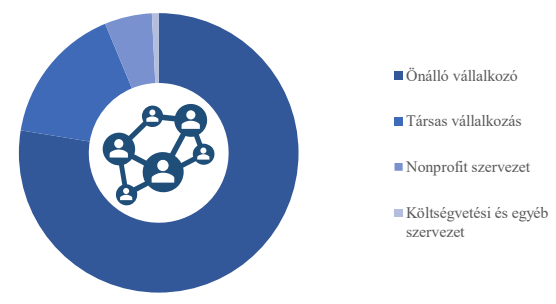

(b)

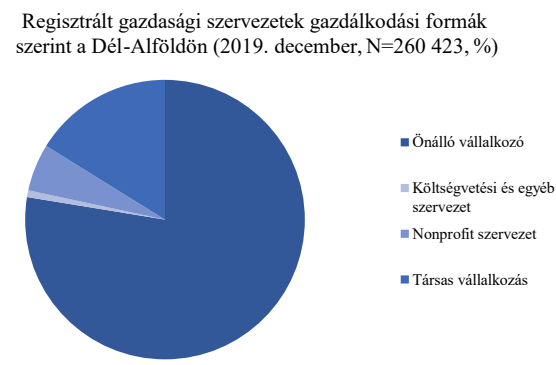

(d)

Regisztrált gazdasági szervezetek gazdálkodási formák szerint a Dél-Alföldön (2019. december, N=260 423,\%)

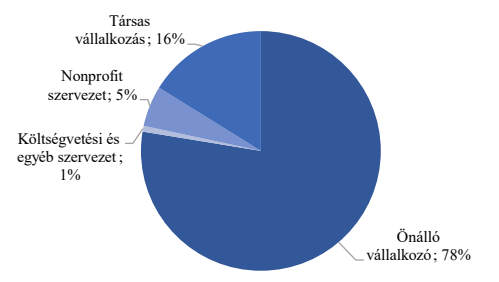

a) kördiagram, a körcikkek óramutató járásával csökkenő sorrendben, b) kördiagram, két legnagyobb körcikk fent, körcikkek óramutató járásával ellentétesen csökkenő sorrenben, c) perecdiagram (lyukas kördiagram ábrával), d) kördiagram körcikkkfeliratozással Forrás: KSH adatok alapján saját szerkesztés.

Ajánlások:

- Egy kördiagramon ötnél több kategóriát ne szerepeltessünk! A túl sok (és kis méretü) körcikk nehézzé teszi az adatok áttekintését, megértését. Ha ennél több kategóriánk van, vagy több kicsi, akkor azokat célszerü összevonni, természetesen úgy, hogy ebben az „egyéb” kategóriában ne legyen elrejtve lényeges információ.

- Ne használjunk egyszerre több körcikket összehasonlításhoz! Kördiagramok körcikkeit nehéz egymással összehasonlítani, akkor is, ha azok egymás mellett vannak; erre a feladatra a 100\%-ig halmozott oszlop tökéletesen megfelel.

- Ügyeljünk arra, hogy az adataink összege 100\% legyen és a körcikkek mérete is ennek megfelelö legyen! 
- Rendezzük a körcikkekkel ábrázolt adatokat úgy, hogy: (1) a legnagyobb körcikk 12 óránál kezdődjön, majd haladjunk csökkenő sorrendben az óramutató járásának megfelelően, vagy (2) a legnagyobb körcikk 12 óránál kezdődjön, tőle balra (az óramutató járásával ellentétesen) következzen a második legnagyobb, majd haladjunk csökkenő sorrendben az óramutató járásával ellentétesen!

A 8. ábra a kördiagramok gyakori hibáit mutatja.

\section{8. ábra: Kördiagramok készítése során elkövetett hibák}

(a)

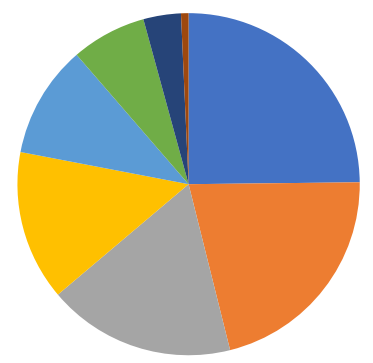

(c)

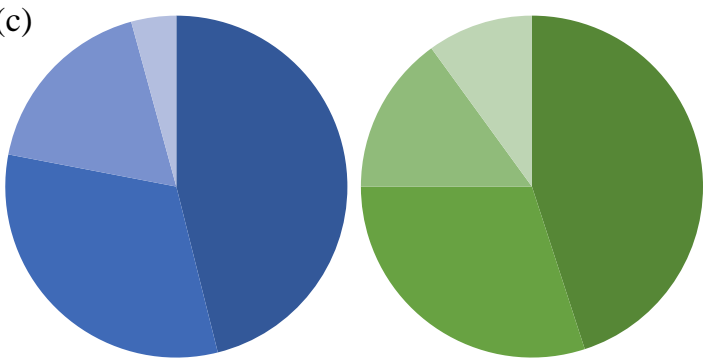

(b)

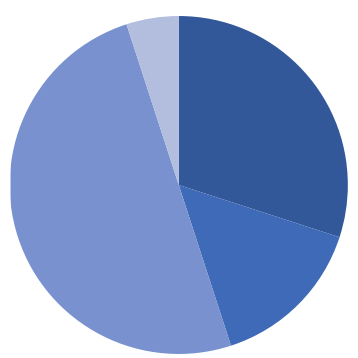

(d)

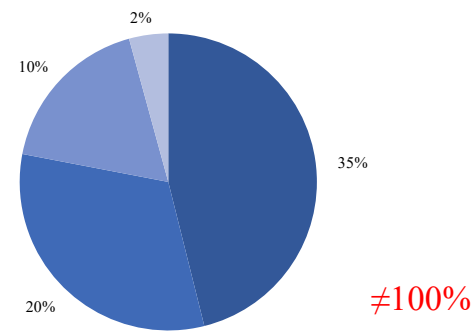

(e)

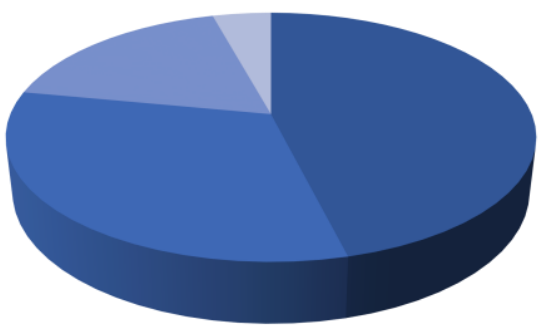

a) túl sok különböző színű és méretű körcikk össze-vissza, b) körcikkek nem megfelelő sorrendben,

c) összehasonításhoz két adatsor két kördiagramon 100\%-ig halmozott oszlop helyett,

d) a körcikkek összege nem $100 \%$, e) harmadik, információtartalom nélküli dimenzió Forrás: saját szerkesztés.

\subsection{Vonaldiagram}

A vonaldiagramot idősor és valamilyen folytonos adat közötti kapcsolat szemléltetésére használhatjuk. Alkalmas változás, trend, gyorsulás, lassulás, volatilitás ábrázolására (lásd: 9. ábra). 


\section{9. ábra: Vonaldiagram}
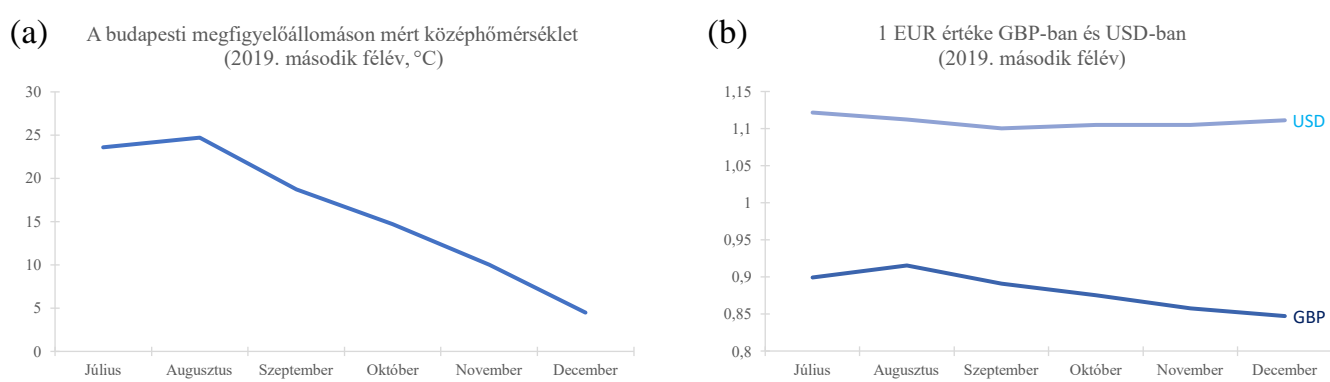

a) egy adatsor, b) két adatsor jelmagyarázattal a vonal mellett Forrás: KSH adatok alapján saját szerkesztés.

A 10. ábrán a vonaldiagramok készítése során gyakran elkövetett hibák láthatók.

\section{0. ábra: Vonaldiagramok készítése során elkövetett hibák}

(a)

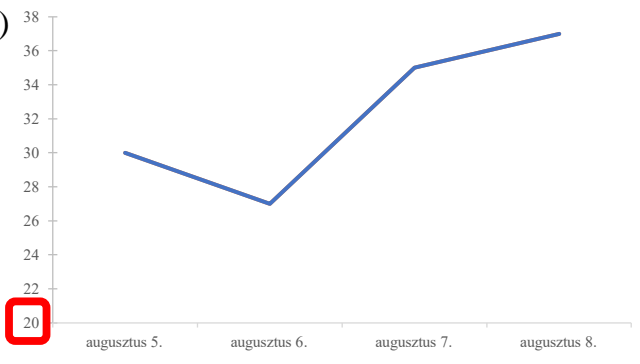

(c)

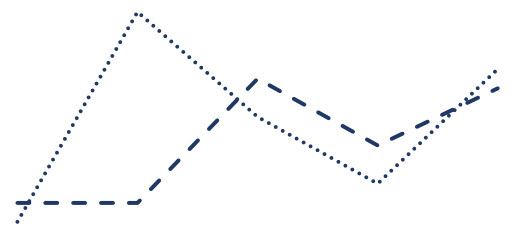

(b)

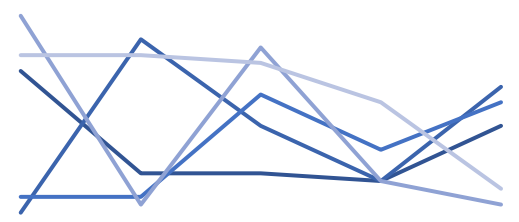

(d)

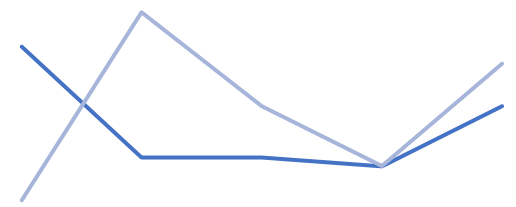

(e)

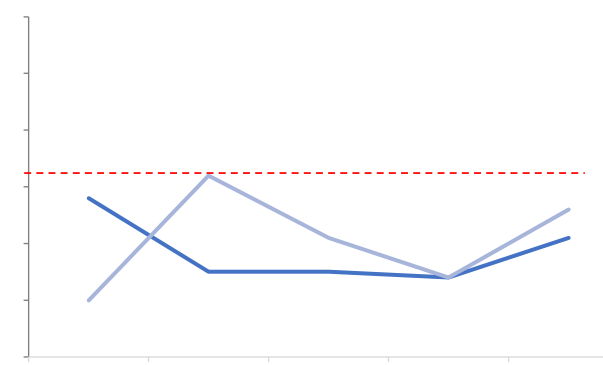

a) nem 0 kezdőpont (kivéve speciális eseteket), b) túl sok, nehezen áttekinthető adatsor, c) nem folytonos, nehezen követhető vonal, d) jelmagyarázat nem a vonal mellett,

e) túl hosszú függőleges tengely

Forrás: saját szerkesztés. 
Ajánlások:

- Ugyan lehetnek kivételek (például tőzsdei árfolyam, valutaárfolyam, vagy ha kicsi az értékek közötti változás, ingadozás), de ha mód van rá, a két tengely $\mathrm{y}=0$-nál metssze egymást!

- Diszkrét adatok ábrázolására ne használjuk ezt a diagramtípust, hiszen a vonal azt sugallja, hogy léteznek köztes értékek is, amelyek diszkrét adatok esetében a valóságban nincsenek!

- Négynél több vonalat ne rajzoljunk egy diagramra, mert ettől már nagyon nehezen áttekinthetővé válhat az ábra! Négynél több adatsor esetén bontsuk ketté az ábrát!

- Csak folytonos vonalat használjunk, a szaggatott vonal zavaró lehet!

- A vonalakat közvetlenül, a vonal mellett címkézzük fel, ott lássuk el jelmagyarázattal, ne az ábra mellett (azaz ne alatta, felette, jobb vagy bal oldalon)!

- Állítsunk be olyan függőleges tengely magasságot, hogy a vonal legmagasabb pontja körülbelül a tengely magasságának kétharmadánál legyen!

\subsection{Terület}

A területdiagram - hasonlóan a vonaldiagramhoz -, szintén egy idősor kapcsolatát szemlélteti egy másik folytonos adatsorral. A különbség „csupán” annyi, hogy itt lehetőség van mennyiségek, összegek, részek és egészek viszonyának megjelenítésére is. Az oszlopdiagramhoz hasonlóan itt is van halmozott változat (lásd: 11. ábra).

\section{1. ábra: Területdiagram}

(a)

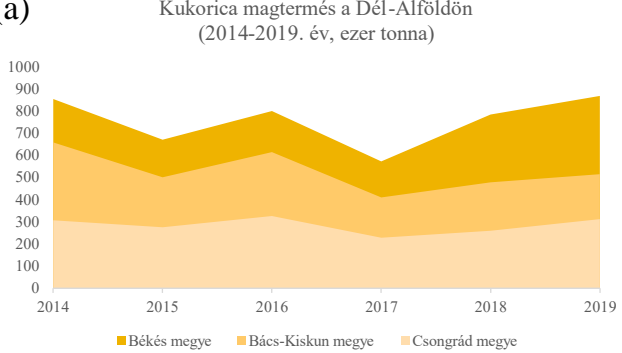

(b)

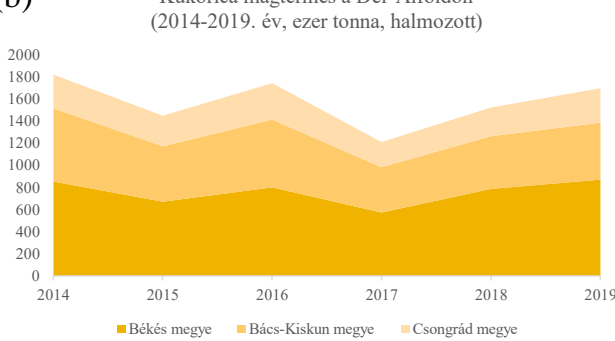
(c) Kukorica magtermés megoszlása a Dél-Alföldön
$(2014-2019$. év, \%)

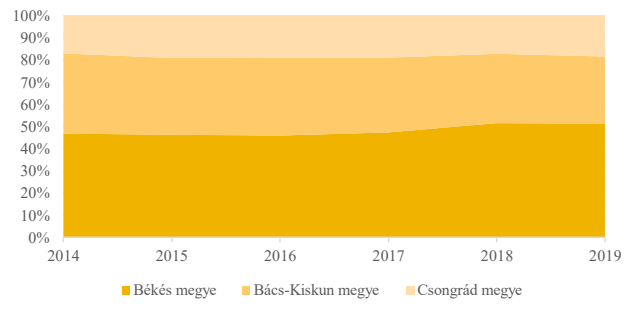

a) területdiagram, b) halmozott területdiagram, c) 100\%-ig halmozott területdiagram Forrás: KSH adatok alapján saját szerkesztés. 
Ajánlások:

- A két tengely az y=0 pontban metssze egymást!

- Diszkrét adatok ábrázolására ne használjuk ezt a diagramtípust, hiszen az ábrázolási mód azt sugallja, hogy léteznek köztes értékek is, amelyek diszkrét adatok esetében a valóságban nincsenek!

- Négynél több adatsort ne ábrázoljunk! Ha nagy az értékek közötti mozgás, eltérés, akkor egyes területek akár többször is átfedésbe kerülhetnek, nehezítve az ábrázolt információ megértését.

- Rendezzük, pozícionáljuk az adatsorokat úgy, hogy a legnagyobb legyen legfelül, a legkisebb legalul annak érdekében, hogy minél kevésbé takarják el egymást!

- Ha mégis van olyan adatsorunk, amely takarásban van, használjunk áttetsző színeket!

A 12. ábra a területdiagramok készítésekor gyakran elkövetett hibákat mutatja.

\section{2. ábra: Területdiagramok készítése során elkövetett hibák}

(a)

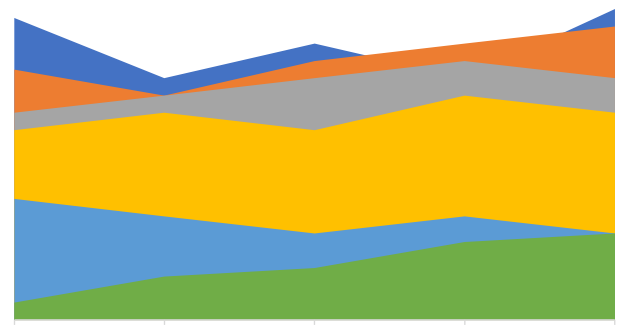

(c)

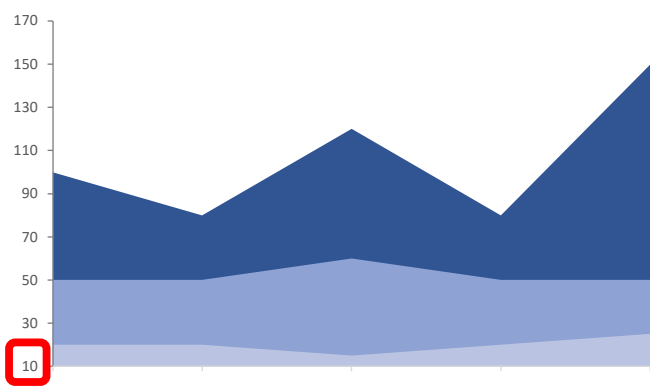

(b)

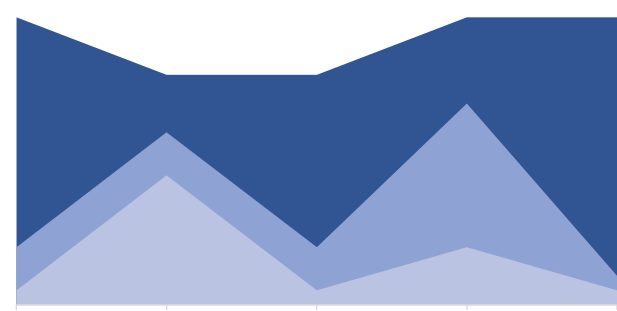

(d)

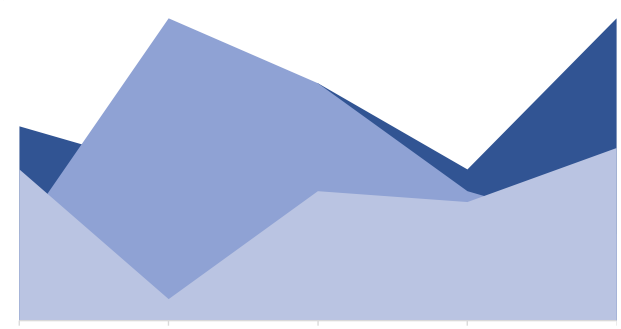

(e)

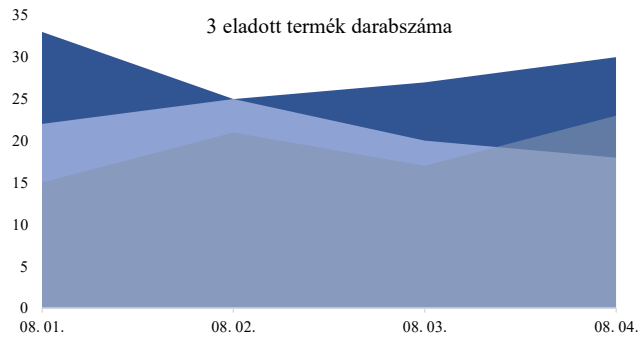

a) túl sok, különböző színủ adatsor, b) adatsorok nem megfelelő sorrendben, c) nem 0 kezdőpont, d) adatsorok takarásban, e) folytonos helyett diszkrét adatok a diagramon Forrás: saját szerkesztés. 


\subsection{Pontdiagram (XY-diagram)}

A pontdiagram összetartozó értékpárok derékszögü koordinátarendszerben való ábrázolására, adatok közötti kapcsolatok - leginkább adatok között korreláció -, vagy annak hiánya szemléletes megjelenítésére használható (lásd: 13. ábra).

\section{3. ábra: Pontdiagram}

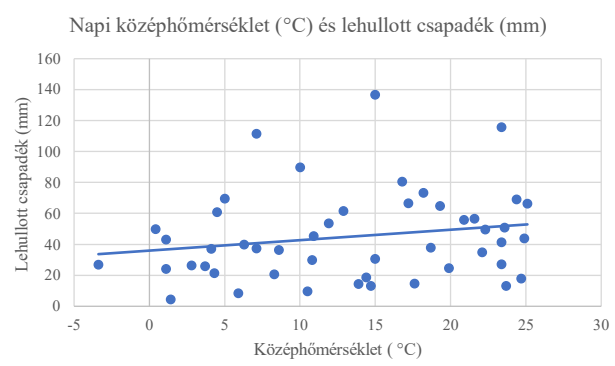

Forrás: KSH adatok alapján saját szerkesztés.

A 14. ábrán a pontdiagramok készítésekor sürün elkövetett hibák láthatók.

\section{4. ábra: Pontdiagramok készítése során elkövetett hibák}

(a)

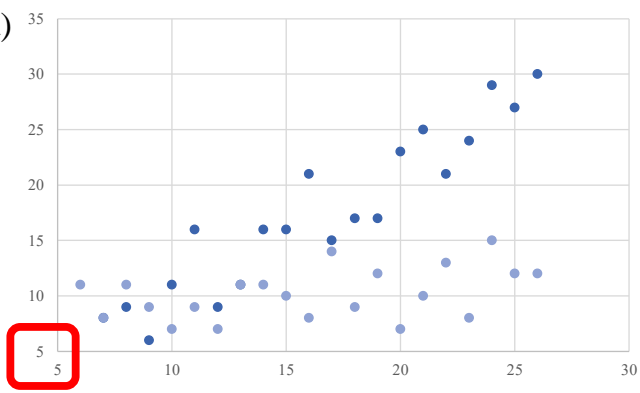

(c)

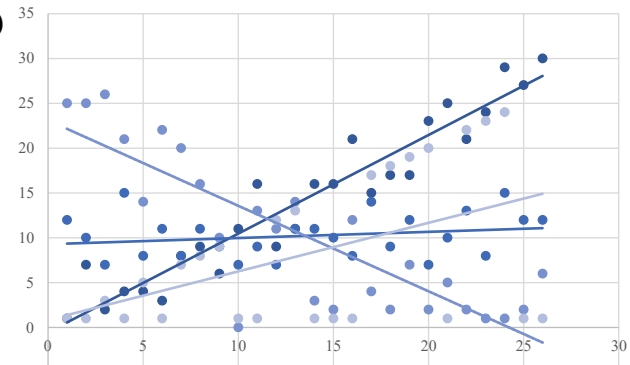

(b)

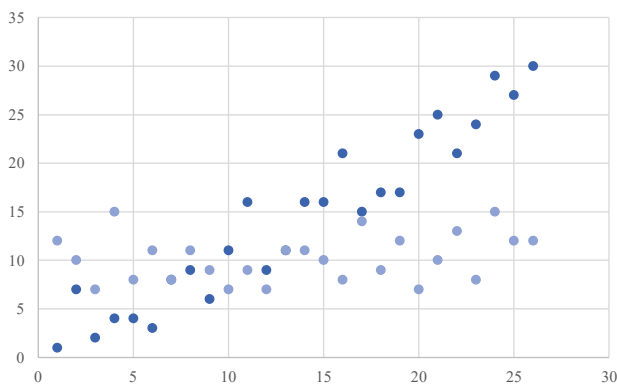

(d)

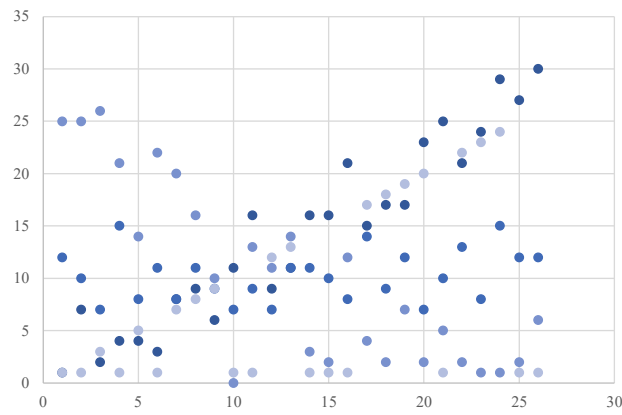

a) nem 0 kezdőpont, b) a ponthalmazból nehezen kiolvasható trend, c) túl sok adatsor és trendvonal,

d) túl sok információ 2 dimenzióban, amely áttekinthetővé tehető például a pontok méretének változtatásával (lásd :buborékdiagram)

Forrás: saját szerkesztés. 
Ajánlások:

- A két tengely az $\mathrm{y}=0$ pontban metssze egymást!

- Illesszünk az adatainkra trendvonalat! A trendvonal segít az adatok közötti összefüggések könnyebb átlátásában.

- Kettőnél több trendvonalat ne illesszünk és hasonlítsunk össze egy ábrán! A túl sok pont és illesztett trendvonal csak nehézzé teszi az értelmezést.

- Alapeseteben két információt jelenítünk meg - ezek a két tengelyen felvett értékek. További információ bevitelére használhatunk színeket vagy eltérő pontméreteket (ami a meglévő kettő mellett még további két dimenziót jelent), ugyanakkor ez már nehezen áttekinthetőve teszi az ábrát!

\subsection{Buborékdiagram}

A buborékdiagram tulajdonképpen a pontdiagram egyik változata, ahol a pontok (buborékok) mérete (és színe) nyújt többletinformációt. Elsősorban összehasonlításra, rangsorolásra használható ábratípus. Alkalmazható koordinátarendszerben, vagy akár térképen is (lásd: 15. ábra).

\section{5. ábra: Buborékdiagram}

(a)

A Dél-Alföld területe, lakossága és a részvénytársaságok száma száma (2019)

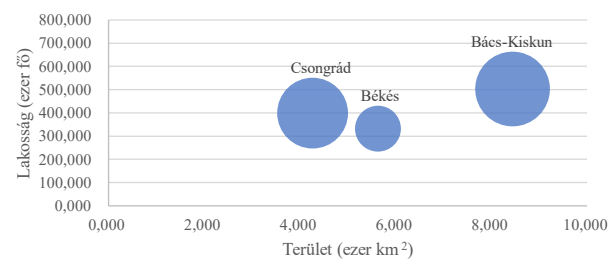

(b)

Egy före jutó GDP (2017, EUR)

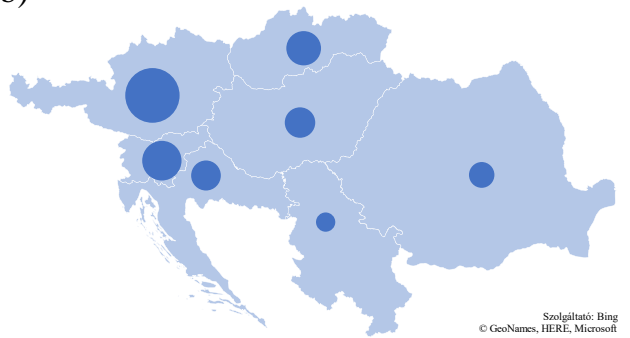

a) a buborék területe a részvénytársaságok számának függvénye, b) az ország területére rajzolt buborék területe az 1 före jutó GDP függvénye Forrás: KSH adatok alapján saját szerkesztés.

Ajánlások:

- A feliratok megfelelő méretüek, jól elkülönültek legyenek annak érdekében, hogy a buborékokban hordozott információ kiolvasható legyen!

- A buborékok méretének megadásakor figyelembe kell venni, hogy nem az átmérőjük, hanem a területük számít!

- A buborék helyett ne használjunk szokatlan - nem kör alakú - formákat, mivel azok csak nehézzé teszik az értelmezést!

A 16. ábra néhány, a buborékdiagramok készítésekor elkövetett hibát mutat. 


\section{6. ábra: Buborékdiagramok készítése során elkövetett hibák}

(a)

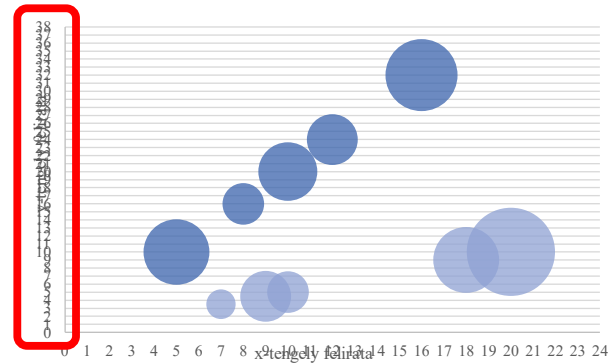

(b)

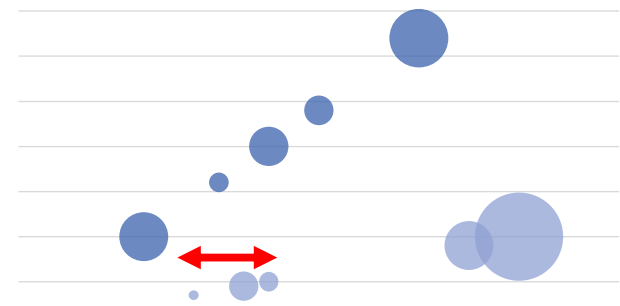

(c)

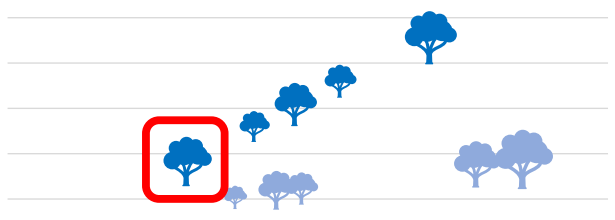

a) egymást átfedő, takaró feliratozás, b) a buborék területének ábrázolása helyett az átmérő ábrázolása, c) nehezen értelmezhető figurális ábrázolás a kör alakú buborék helyet Forrás: saját szerkesztés.

\subsection{Hőtérkép}

A hőtérkép diagrammal térképen ábrázolhatunk numerikus adatokat, úgy, hogy egy színárnyalat intenzitása jelzi az adat nagyságát egy intervallumon belül, ezzel téve lehetővé a szemléletes összehasonlítást (lásd: 17. ábra).

\section{7. ábra: Hötérkép}

(a)

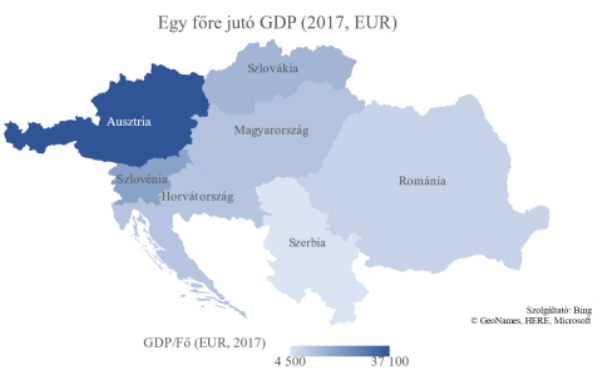

(b)

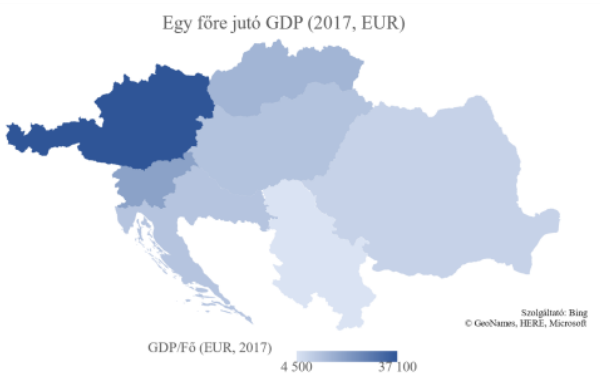

hőtérkép a) a területek (országok) egyértelmű megnevezésével és b) anélkül Forrás: KSH adatok alapján saját szerkesztés.

Ajánlások:

- Válasszunk megfelelő színeket! Egyes színek jobban kitűnnek, feltűnőbbek a többinél ezzel hangsúlyosabbá téve az adatot. Különböző színek helyett célszerübb egy szín különböző színárnyalatait, vagy analóg (egymással 
harmonizáló) színeket használni úgy, hogy a kisebb értékeket halványabb, a nagyobb értékeket sötétebb színárnyalatok jelképezzék.

- Állítsunk be legalább három és legfeljebb öt (közel) azonos nagyságú intervallumot, amelyet eltérő színárnyalatokkal ábrázolunk!

- Mintákat csak óvatosan alkalmazzunk! A színárnyalatok mellett a minták alkalmasak lehetnek egy újabb információ megjelenítésére, de sokféle minta alkalmazása már zavaró lehet.

A 18. ábra a hötérkép készítésekor elkövetett néhány gyakori hibát illusztrál.

\section{8. ábra: Hőtérképek készítése során elkövetett hibák}

(a)

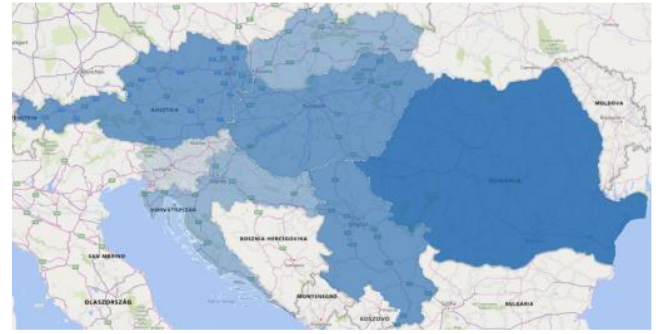

(b)

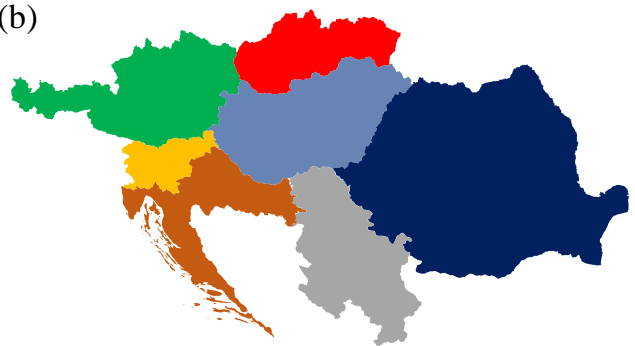

(c)

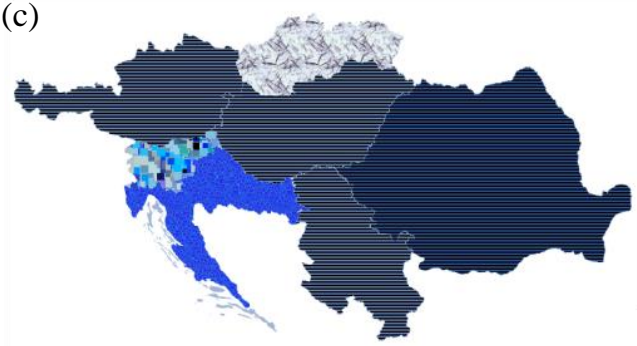

a) lényegtelen részletek a térképen, b) nem megfelelő színek használata, c) túl sok, nehezen értelmezhető információ a színek és a minták együttes alkalmazásával Forrás: saját szerkesztés.

\section{Záró gondolatok}

Az információ hatékony átadásában a grafikus ábrázolás - köztük a diagram is jelentős szerepet játszhat, feltéve, hogy megfelelően használjuk azt.

Egy diagramot annak tudatában célszerü elkészíteni, hogy az ember információbefogadó és információfeldolgozó képessége korlátos. Sok, a célnak megfelelő számítógépes program áll rendelkezésre a megoldási lehetőségek széles skálájával, azonban nem feltéltlenül kell (vagy szabad) az összes lehetséges, illetve alapértelmezés szerint felkínált megoldási javaslatot elfogadni és alkalmazni gondolhatunk itt akár az adatábrázoláshoz alapesetben felkínált diagramtípusra, vagy a színkombinációkra, a tengelyek beosztására stb.

Zárásként egy ábra annak illusztrálására (lásd: 19. ábra), hogy még egy program is tévedhet: az alapértelemzés szerint létrehozott ábra nem felel meg az adott diagramtípussal szembeni követelményeknek, ezért azt módosítani kell, amihez az adott diagramtípussal kapcsolatos szakmai ismeret szükséges. 


\section{9. ábra: Gyakorisági hisztogram}

(a)

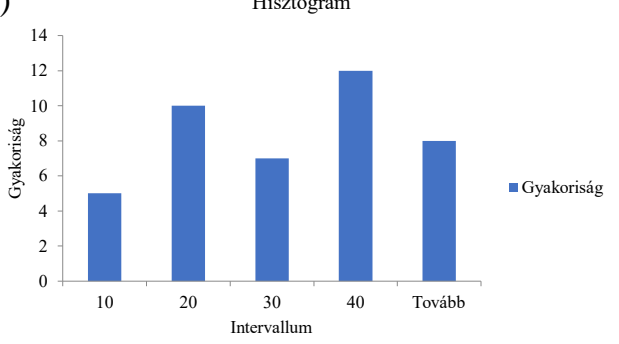

(b)

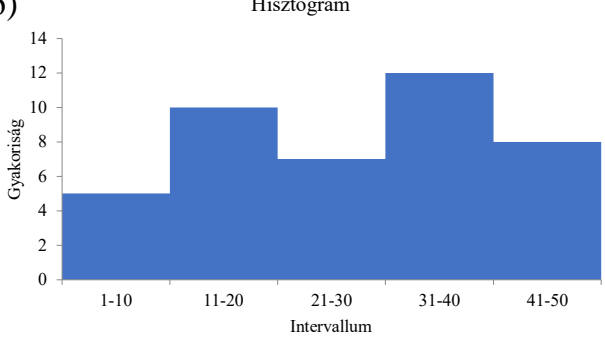

a) A Microsoft Excel Adatalemzés/Hisztogram bővítményének eredménye: hisztogram, valójában oszlopdiagram, az oszlopok között térköz van, az oszlopok területe helyett azok magassága számít,

b) az alapértelmezés szerinti beállításokat manuálisan kell módosítani a helyes ábrához

Forrás: saját szerkesztés.

\section{Irodalomjegyzék}

Atkinson, R., Shiffrin, R. (1968): Human memory: A proposed system and its control processes. In: Spence, K., Spence, J.(szerk.): The psychology of learning and motivation: Advances in research and theory (Vol. 2). Academic Press, New York.

Bodnár I., Magyary G. (2005): Az informatika elméleti alapjai. Kiskapu Kft., Budapest.

Eddy, M. D. (2020): Diagrams. In: Grafton, A., Blair, A., Goeing, A. S. (szerk.): A Companion to the History of Information. Princeton University Press, Princeton. 397-401.

Fabulya Z. (2017): Hőkezelési folyamatok összehangolása Excel VBA szolgáltatásokkal. Jelenkori társadalmi és gazdasági folyamatok, 12 (4): 19-25.

Hampel Gy., Heves Cs. (2019): Informatika alapjai mérnököknek, alapszakos hallgatók számára. Szegedi Tudományegyetem, Szeged.

HubSpot (2014): Data Visualization 101: How to design charts and graphs. HubSpot+Visage. <https://blog.hubspot.com/marketing/types-of-graphs-for-data-visualization> (2018.09.02.)

Domán Cs., Szilágyi R., Varga B. (2007): Statisztikai elemzések alapjai. Közgazdasági-módszertani képzés fejlesztéséért Alapítvány, Miskolc

Juhász S. (2011): Vállalati információs rendszerek müszaki alapjai. Szak Kiadó, Budapest.

Kacsukné B. L., Kiss T. (2009): Bevezetés az üzleti informatikába. Akadémiai Kiadó, Budapest.

Wickens, Ch. D., Hollands, J. G., Banbury, S., Parasuraman, R. (2013): Engineering Psychology and Human Performance. Psychology Press, New York. 